\title{
K památce a pedagogickému odkazu Idy Jarníkové
}

\section{Ke 100. výročí jejího zásadního vystoupení na Prvním sjezdu Československého učitelstva a přátel školy v roce 1920}

KAREL RÝDL

\begin{abstract}
Abstrakt: $K$ málo známému výroči nabizí studie analyzu života a díla Idy Jarníkové (1979-1965), jedné z nejvýznamnèjš́ch prèdstavitelek prèdškolni výchovy 20. století. Na základè studia archivnich dokumentů studie zdưrazňuje nejen životni osudy, poprvév ucelené podobè, ale zvlástě Jarníkové predstavy o pedagogizaci predškolni výchovy ve prospěch rozvoje osobnosti dètí, jeji snahu o porozumèni pedagogice Marie Montessori a péći o dalši vzdèláváni vychovatelek $v$ mateřských školách. Studie je doplnèna výbèrovou bibliografí Idy Jarníkové.
\end{abstract}

Klićová slova: sociální péče, predškolní výchova, Ida Jarniková, Marie Montessori, inovace výchovy

\section{ÚvoD}

Během konání Prvního sjezdu československého učitelstva a přátel školství v osvobozené vlasti (Praha 1920) měla dvě zásadní vystoupení ve prospěch zefektivnění výchovy dětí v mateřských školách Ida Jarníková. Tehdejší, ale i současné profesní společnosti na ně reagovaly bud' mlčením, nebo otevřením diskusí o možnostech uskutečnění jejích požadavků v praxi. I když tyto požadavky byly prosazovány pomalu a spíše jednot- livě v průběhu dalších sto let, po celou dobu se Ida Jarníková, často ve spolupráci s dalšími odborníky, vychovatelkami a učitelkami, snažila na nutné změny nezapomínat a prosazovat je. Zejména její zásluhou se již během období tzv. první republiky podařilo vnímat předškolní zařízení nikoli jen jako instituci sociální, ale především pedagogickou, nikoli tedy jen zaopatřovací, ale především výchovnou a vzdělávací.

Cílem studie je připomenout Idu Jarníkovou jako výraznou osobnost $\mathrm{v}$ utváření 
diskuse o pedagogickém obsahu předškolní výchovy především v meziválečném období $s$ důrazem na proreformní pojetí vědeckého, ale i laického diskurzu.

Metodologicky je text postaven na výsledcích heuristického průzkumu a interpretaci archivních pramenů s cílem rekonstruovat život a dílo Idy Jarníkové ve smyslu jejího postavení v národním, ale i evropském rozměru reformně pedagogických snah s důrazem na pedagogizaci tehdejší předškolní výchovy orientované převážně na cíle sociální a zdravotní.

Vedle analýzy archivní pozůstalosti Idy Jarníkové, uložené v Národním pedagogickém muzeu J. A. Komenského v Praze, autor využil i pozůstalost Josefa Kubálka, uloženou v SOkA Hradec Králové, a dále fondy Národního archivu ČR v Praze. Autor se také pokusil o analýzu dosavadní sekundární literatury o Idě Jarníkové, která vykazuje dvě obsahové roviny. $\mathrm{V}$ první rovině najdeme přehledové krátké studie vzpomínkového charakteru, uveřejněné zejména $\mathrm{v}$ domácích odborných časopisech pro předškolní výchovu (Štastná, 1975/1976; Lacinová, 1991/92; Fottová, 1996; Uhlírová, 2003), a také velmi stručná slovníková hesla (viz bibliografie). Druhou rovinu charakterizují články nebo kapitoly $\mathrm{v}$ knihách, které se pokoušejí podat přehled o pedagogických názorech Idy Jarníkové na základě analýzy její odborné knižní produkce (Pražák, 1927; Spěváček, 1975; Mišurcová, 1982; Dvořáková, 1987; Baduríková, 1999).
Text tak přináší díky pečlivému archivnímu bádání a analýze sekundární literatury nové a poprvé i ucelené informace o životě a díle Idy Jarníkové ve třech obsahových rovinách a ukončuje tak téměr dvacetileté mlčení o činnosti této osobnosti. Autor vykresluje Jarníkovou jako pracovnici učitelského hnutí se snahami ve vzdělávání učitelek a vytváření jejich profesních sdružení. Druhou rovinu představuje začlenění Idy Jarníkové do reformně pedagogických meziválečných snah $s$ důrazem na její snahu o porozumění a využití pedagogiky montessori v československém prostředí, z čehož pak vychází rovina třetí, kterou autor věnuje institucionalizaci reformních snah v podobě experimentů v pražské holešovické mateřské škole.

Jednotlivé roviny jsou propojeny a usilují o intepretaci a „znovuzasazení významné představitelky reformně pedagogické diskuse do širších souvislostí meziválečného hnutí za novou školu a novou výchovu (Rýdl, 1997; Kasper \& Kasperová, 2020). Ida Jarníková je pedagogickou osobností, která významným způsobem deklaruje úsilí žen-učitelek o reformu školy, dále mimořádným způsobem poukazuje na významné postavení žen-učitelek ve spolčování meziválečného učitelstva. Rovněž je osobností, která ztělesňuje propojování českého (československého) reformně pedagogického hnutí se světovými trendy (Kasper, Kasperová \& Pánková, 2018). Nejen zájem Idy Jarníkové o pedagogiku Marie Montessori a "transfer" její metody do české peda- 
gogické diskuse, ale i reflexe širších reformně pedagogických proudů do české diskuse představuje důležitý aspekt její pedagogické práce. $\mathrm{V}$ tomto ohledu je možno číst Jarníkovu jako pedagožku, která poukazuje na čilé „sítování“ českého a mezinárodního pedagogického hnutí. Následující studie se opírá nejen o životní etapy Jarníkové, o její „ideové“ pedagogické přesvědčení, ale rovněž o analýzu mimořádně zajímavého a pro tehdejší rozvoj předškolního vzdělávání zásadního příkladu reformy mateřské školy - rekonstrukci programu a vývoje pokusné holešovické „školky“.

\section{K ŽIVOTNÍM OSUDU゚M IDY JARNÍKOVÉ}

Ida Jarníková se narodila dne 14. března 1879 ve Vídni. Jejím otcem byl Jan Urban Jarník, v té době učitel francouzštiny na reálných školách ve vídeňské čtvrti Leopoldov. ${ }^{1}$ Matka se jmenovala Henrietta Jarníková, rozená Eisselt von Klimpeli, jak uvádí jediný dostupný pramen, totiž křestní list Idy Jarníkové z 23 . března 1879 , vyhotovený farním úřadem u sv. Štěpána ve Vídni. ${ }^{2}$ $\mathrm{V}$ době narození měla Ida již více než ročního bratra Hertvika a v roce 1897 se manželům Jarníkovým narodil druhý syn Vojtěch. ${ }^{3}$ Mezitím se ještě narodily dvě dcery, z nichž jedna záhy po narození zemřela na černý kašel a druhá, Jarmila, se stala učitelkou obecné, později i základní školy a žila s neprovdanou Idou ve společné domácnosti v Praze.

$\mathrm{V}$ dochovaných rukopisných poznámkách k vlastnímu životopisu popisuje Ida Jarníková vzpomínky na vlastní dětství v Praze na Smíchově a později

\footnotetext{
1 Jan Urban Jarník (1848-1923) proslul jako vynikající český jazykovědec specializující se na románskou komparativní filologii. Po absolvování vídeňské univerzity (1874), studiu na pařížské Sorbonně (1875), doktorátu filozofie (1876), habilitaci (1878) a studijních cestách do Sedmihradska a Rumunska začal vyučovat na reálných školách ve Vídni. Po vzniku české pražské univerzity byl na ni povolán v roce 1882 a založil zde seminář románské filologie, první v rakouské monarchii. Po celý život se věnoval rumunštině, psal v ní odborné knihy, překládal českou literaturu (Babička) a byl jmenován čestným členem Rumunské akademie věd v Bukurešti. Dodnes je v Rumunsku považován za významného „domácího“ spisovatele. Svůj zájem věnoval také albánskému etniku a studiu sánskrtu. Vedle filologické činnosti, která ho dovedla až k titulu důstojníka Francouzské akademie v Paříži, České akademie a České společnosti nauk v Praze, se od roku 1882 věnoval podpoře spolkové činnosti. V letech 1904-1923 stál v čele Svazu českých spolků okrašlovacích a na ochranu domoviny v Čechách, na který dnes navazují čeští ochránci přírody. Profesor Jarník také výrazně podporoval nemajetné studenty, staral se o zlepšování jejich sociální situace a podporoval jejich akademické spolky. Za tuto činnost byl nazýván „otcem studentů“. Jan Urban Jarník byl pochován na pražském olšanském hřbitově za účasti několika velvyslanců a ministrů školství románských zemí. V témže roce byla v pražské akademické menze odhalena pamětní deska $s$ jeho bustou. [Srov. Moravec, 2003, s. 19; Kolektiv autorů. (1993). Kdo byl kdo v našich dějinách do roku 1918. Praha: Libri.]

2 Archiv Národního pedagogického muzea J. A. Komenského (dále NPMK), fond Ida Jarníková, krab. 1, sign. S-374/II-1.

3 Hertvik Jarník (1877-1938) šel ve stopách svého otce a proslul jako vynikající romanista a překladatel na Masarykově univerzitě v Brně [srov. Národni politika, 11. 12. 1938, 61(341), 4.] Mladší bratr Vojtěch Jarník (1897-1970) se stal vynikajícím matematikem na pražské univerzitě (srov. Kořínek \& Vyčichlo, 1958). V jeho stopách pokračuje na PedF UK v Praze také Vojtěchův syn doc. RNDr. Jiř́ Jarník, CSc.
} 
na pražské Malé Straně, během kterého si „hrála více $s$ hochy a panenky neměla moc ráda“. ${ }^{4}$ Hezké vzpomínky má ale Ida i na prázdninové pobyty v rodinném letním domku v Potštejně nad Orlicí, kde žili její dědeček a babička, kteří ji naučili mnoho ze svého skromného venkovského života a $\mathrm{z}$ dnes již zapomenutých ručních prací, využitelných Idou později v návrzích výchovných programů mateřských škol, např. paličkování. ${ }^{5}$ Rodiče si uvědomovali silný zájem dospívající Idy o práci s malými dětmi, protože mohli denně pozorovat její péči o nově narozenou sestřičku a bratra Vojtěcha. Otec tehdy velmi moudře rozhodl zkontaktovat počátkem devadesátých let 19 . století svoji dceru s Boženou Studničkovou, tehdy v Praze asi nejznámější vychovatelkou předškolních dětí. V její mateřské škole mohla Ida pozorovat práci s malými dětmi a později se do ní pod dohledem Boženy Studničkové i zapojovat. ${ }^{6}$ Osobnost Boženy Studničkové a její mateřský vztah $\mathrm{k}$ malým dětem Idu tak nadchl, že se rozhodla vykonávat ve svém životě tutéž práci. ${ }^{7}$

$\mathrm{Na}$ tehdejší dobu silně nadprůměrný zájem o práci s malými dětmi dokazuje i zachovaný útlý svazeček rukopisných rad a promluv $\mathrm{k}$ malým dětem, které Ida Jarníková psala $\mathrm{v}$ průběhu prosince 1889 až července 1890 pod názvem Pomněnky. Rady dětem z vlastní zkušenos$t i{ }^{8} \mathrm{~V}$ osmnácti promluvách, které byly věnovány etickým pravidlům chování a způsobům vlastního zdokonalování se v soužití se společností, čerpala Ida Jarníková ze vzpomínek na vlastní dětství. Všechny její promluvy jsou z hlediska obsahu aktuální dodnes, jejich forma a jazyk odpovídá ovšem konci 19. století. Pro ukázku uvádíme alespoň výňatek z promluvy ze dne 30 . června 1890 , která se týkala upřímnosti a závisti: „Závist je nejhorší nemoc, praví př́ísloví. A skutečně není nemoci, jež by tak tělo i ducha hubila jako závist, a jest ona ještě těžší nemocí duševní než tělesná. Běda tomu, kdo ji nechá přestoupiti přes práh srdce svého." Když Ida Jarníková odcházela ze cvičné školy, zanechala nám v Pomněnkách nejen seznam svých spolužaček, ale jedné z nich (Marii Kohoutové) svěřila i dokončení Pomněnek pro děti ze cvičné školy. Pomněnky končí větou: „Dobré chtíti je krásné, dobře činiti je lepší!“

Bylo tedy víceméně jasné, že po ukončení měštanské školy se Ida Jarníková, silně motivovaná vlastní-

\footnotetext{
4 Poznámky k vlastnímu životopisu. Archiv NPMK, fond Ida Jarníková, sign. S-374/II-2, s. 1.

5 Jarníková, I. 1927. Výchovný program materských škol.

6 Tamtéź.

7 Božena Studničková (1849-1934) byla vynikající dětskou básnírkou, spisovatelkou a opatrovnicí v mateřských školách. Působila dlouhodobě jako ředitelka mateřské školy a angažovala se od roku 1904 jako předsedkyně ženského esperantského spolku při Náprstkově muzeu v Praze.

8 Archiv NPMK, fond Ida Jarníková, krab. 1, sign. S-374/II-5, 485/74.

9 Tamtéž.
} 
mi praktickými zkušenostmi z rodiny i praxe $\mathrm{v}$ mateřské škole, zapsala ke studiu na c. k. českém ústavu ku vzdělání učitelek v Praze, který ukončila v roce 1898. Zachované vysvědčení způsobilosti za pěstounku ve škole mateřské nese datum 19. června $1898 .{ }^{10}$ Celkový prospěch „chvalitebně“ činil průměrnou známku z osmi předmětů závěrečných zkoušek (náboženství, nauka o vychovatelství a teorie mateřské školy, praktické pokusy ve škole mateřské, jazykové a věcné vyučování, kreslení od ruky, výtvarné projevy, zpěv a tělocvik) a Ida Jarníková se mohla pochlubit podpisy sedmi učitelů, mezi nimi např. Jana Maška, Věnceslava Černého nebo Josefa Šauera z Augenburku. Mezitím ovšem nad rámec školních povinností studovala hudbu, cizí jazyky a absolvovala kurzy šití a domácího hospodářství. $\mathrm{V}$ témže roce, kdy ukončila na učitelském ústavu vychovatelský kurz pro pěstounky v mateřských školách (1898) se Jarníkovým narodil syn Vojtěch. V té době již čerstvě kvalifikovaná a pedagogicky vzdělaná Ida si malého bratříčka velmi oblíbila a věnovala mu podstatnou část svého volného času. Ve svých vzpomínkách píse, že malý Vojtíšek se stal oblíbencem nejen rodiny a príibuzných (nové miminko v rodině, kde ostatní děti jsou již dospělé), ale i zná- mých, např. rodiny tatínkova kolegy prof. Jana Gebauera. ${ }^{11}$ Rodina Jana Gebauera měla na Idu Jarníkovou velmi silný vliv svojí soudržností a vnitřní rodinnou atmosférou. ${ }^{12}$ Ida Jarníková vzpomíná, jak ji péče o malého bratra doslova pohltila a z pečlivého pozorování bratrova rozvoje potom analyzovala jeho potřeby a snažila se je maximálně naplňovat. „A přirozeně promítala jsem později všechnu práci v mateřské škole zkušenostmi z pozorování bratříčka. A tak jsem patrně došla ke snahám reformním: chtěla jsem, aby děti v mateřské škole měly tolik pohybu, čerstvého vzduchu a radostí jako dítě, jež bylo obklopeno láskou nás všech. $\mathrm{Na}$ něm (na bratrovi Vojtěchovi, pozn. autora) jsem si ověřovala vhodnost i nevhodnost některých zařízení a některých částí programu." ${ }^{13}$

$\mathrm{V}$ přištích zaměstnáních a práci $s$ dětmi vždy uplatňovala své vrozené, rodinou a sebevzděláváním rozvinuté předpoklady, totiž vysokou citlivost pro psychický stav dítěte a hudební a výtvarný vkus.

Od počátku svého odborného vzdělávání se Ida Jarníková věnovala zejména dosavadnímu vývoji předškolní pedagogiky. Její v pozůstalosti zachované četné zápisky a výpisky svědčí o velmi podrobném studiu spisů J. A. Komenského,

\footnotetext{
${ }_{10}$ Vysvědčení způsobilosti za pěstounku... Archiv NPMK, fond Ida Jarníková, krab. 1, sign. S-374/III.

${ }^{11}$ Poznámky k vlastnímu životopisu... Tamtéž.

${ }^{12} \mathrm{PhDr}$. Jan Gebauer (1838-1907) byl předním českým jazykovědcem, zakladatelem bohemistiky na české univerzitě v Praze. Zapojil se spolu s T. G. Masarykem do dokazování nepravosti Rukopisů. Věnoval se staročeštině a vývoji českého jazyka, zejména gramatiky.

${ }^{13}$ Poznámky k vlastnímu životopisu ... Archiv NPMK, fond Ida Jarníková, krab. 1, sign. S-374/III, s. 2.
} 
J. V. Svobody, F. Mošnera a B. Ledvinkové, a i prací současnic B. Studničkové a $\mathrm{L}$. Tesařové.

Prvním pracovním místem, kde mohla Ida Jarníková hospitovat, byla mateřská škola v Dušní ulici v Praze, kde pracovala od 1. listopadu 1899 do 15 . července 1990 , ovšem bez nároku na plat. Od 15. zárí 1900 do 20. ledna 1902 hospitovala $\mathrm{v}$ mateřské škole v Klimentské ulici v Praze. ${ }^{14}$ Další rok potom vykonávala polední dozor $\mathrm{v}$ mateřské škole v Dušní ulici a na Maninách. ${ }^{15}$ Několikaletá bezplatná hospitační činnost mladých pěstounek $\mathrm{v}$ předškolních zařízeních bylo na přelomu 19. a 20. století běžně zavedenou praxí. Počátkem října 1903 se jí splnil velký sen, získala pracovní místo výpomocné pěstounky $\mathrm{v}$ mateřské škole U Studánky v Praze-Holešovicích, kde pracovala až do 1 . prosince 1908 , přičemž poslední půlrok pracovala již jako zatímní pěstounka. ${ }^{16}$

V roce 1908 se v Praze konal 5. sjezd pěstounek a Ida Jarníková zde představila plán na reformu mateřské školy (Šmelová \& Rýdl, 2012, s. 39-40). $\mathrm{Na}$ základě rozboru psychického vývoje předškolního dítěte (byla výrazně ovlivněna pracemi pražských univerzit- ních profesorů F. Šerackého a F. Čády) a vlastních několikaletých praktických zkušeností požadovala především účelnější zařízení a vybavení předškolních institucí, které je dnes již samozřejmostí (šatna, herna, jídelna, veranda pro cvičení i odpočinek dětí a zahrada s hřištěm travnatým a pískovým). Místo školních lavic požadovala mobilní stolky a židličky, pro cvičení přiměřené náčiní a nářadí. Učitelky měly studovat zejména psychologii předškolního dítěte, aby dokázaly lépe uspokojovat individuální potřeby dětí.

Přibližně ve stejném době, kdy v Římě začínala Marie Montessori svoje výzkumy dítěte, jejichž výsledky potom využila při koncipování vlastního systému pedagogické péče o předškolní děti, šla stejnou cestou v Praze i Ida Jarníková. ${ }^{17}$ Srovnatelné s návrhy pomůcek Marie Montessori jsou např. návrhy pomůcek v první knížce Idy Jarníkové s názvem Index pomůcek pro školy mateřské a nejnižši třidy školy obecné (1908).

V roce 1910 získala Jarníková místo definitivní pěstounky $\mathrm{v}$ mateřské škole v Josefské ulici v Praze 1, kde působila až do 30. srpna 1920, s dvouletou přestávkou 15. 9. 1910 - 30. 8. 1912, kdy pracovala v mateřské škole v Pštrossově

\footnotetext{
${ }_{14}$ Národní archiv, fond Zemská školní rada. Dekret ze dne 2. 10. 1900 č. 142.993/VI.

15 Tamtéž. Dekret č. 50.755/VI z 20. 3. 1902 a č. 114.663/VI z 27. 6. 1902.

16 Tamtéž. Dekret č. 190.329/VI z 20.10. 1903.

${ }^{17} \mathrm{Na}$ základě porovnání situace a prostředí, ve kterém obě ženy (M. Montessori a I. Jarníková) působily, lze konstatovat, že jejich pedagogické názory jsou velmi blízké, i když se v době před první světovou válkou neznaly, a že se obě dotkly objektivních zákonitostí dětského vývoje, ovšem nezávisle na sobě. Myslím, že kdyby I. Jarníková psala své pozdější práce anglicky nebo alespoň německy, byla by nyní historiky školství ve světě stavěna na úroveň $\mathrm{M}$. Montessori nebo O. Decrolyho.
} 
ulici v Praze jako vedoucí reformního oddělení (srov. Štastná, 1975/1976, s. 380). Zde se pokusila uskutečnit některé ze svých představ a snů ve prospěch psychiky dětí a hned při prvním požadavku narazila. Žádala totiž, aby byly z místností, kde jsou děti, odstraněny kříže s Ježíšem, protože pohled na jeho utrpení kazí radostnou a příjemnou atmosféru. Hrozící propuštění vyústilo $\mathrm{v}$ pouhé přeložení zpět na mateřskou školu v Josefské ulici, kde k její reformní práci nebylo vedení školy původně vstřícné, ale po jejím návratu vzhledem k získaným zkušenostem její představy $\mathrm{z}$ velké části respektovalo. Zde vydržela pracovat až do srpna 1920.

Ida Jarníková poznávala jako cvičná učitelka $\mathrm{v}$ každodenní praxi, že práce $s$ malými dětmi si vynucuje od dospělých neustále se vzdělávat: „Kurzy modelování, prací z lýka, kreslení, aj. vyplňovaly mezery $\mathrm{v}$ naší praktické přípravě. Vědecké přednášky a kurzy (prof. Dra F. Čády, Dra Herforta, Dra Weignera, a.j.) ukazovaly nám vědecké zdůvodnění rané výchovy a podněcovaly $\mathrm{k}$ pozorování dítěte." ${ }^{\text {"18 }}$

$\mathrm{V}$ době těsně před první světovou válkou se Ida Jarníková intenzivně věnovala vlastnímu sebevzdělávání a zúčastňovala se velkého množství nejrůznějších kvalifikačních a prakticky orientovaných kurzů využitelných v běžné každodenní výchovné práci u předškolních dětí. V červnu 1911 podnikla Ida Jarníková studijní cestu do Anglie, kde se zúčastnila vzdělávacího kurzu o nových výchovných směrech $\mathrm{v}$ předškolní pedagogice. Měla možnost navštívit mateřské i obecné školy v Londýně, Oxfordu, Cheltenhamu, Penarthu, Barry a Cadoxtonu. Získala silnou inspiraci pro proměnu práce $\mathrm{v}$ českých mateřských školách, ale odmítala mechanické přejímání cizích vzorů. Vlastní i zahraniční zkušenosti potom uplatnila $v$ návrzích na reformu výchovné práce české mateřské školy, jejíž rysy ověřovala $\mathrm{v}$ mateřské škole v Praze v Pštrossově ulici. Později vydala návrh plánu výchovné práce pod názvem Príručka pro školy mateřské (1911).

V roce 1913 vydala Ida Jarníková spolu s kolegyní Zdeňkou Drobnou sbírku vhodných zaměstnání dětí včetně metodických návodů pro učitelky s názvem Dětský svět (1913) a stala se redaktorkou spolkového Časopisu učitelek mateřských škol, který redigovala až do roku 1927. Zúročila v něm nejen vlastní zkušenosti, ale i rozsáhlý přehled po světovém dění v oblasti předškolní výchovy. V průběhu roku 1913 se Ida Jarníková také aktivně zapojila do cyklu přednášek o pedagogice Marie Montessori.

V roce 1914 se stala od IV. ročníku vedoucí redaktorkou Časopisu učitelek mateřských škol, kterou vykonávala až do roku 1927. ${ }^{19}$ Tím získala i významné postavení ve Spolku pro zájmy škol

\footnotetext{
${ }_{18}$ Poznámky k vlastnímu životopisu... Archiv NPMK, fond Ida Jarníková, sign. S-374/II-2, s. 2.

19 Archiv NPMK, fond Ida Jarníková, krab. 1, sign. S 374/II-9.
} 
mateřských v zemích na Říšské radě zastoupených, v letech 1919-1923 potom $\mathrm{v}$ nástupnické organizaci s názvem Ústřední spolek pro zájmy škol mateřských a spolků $\mathrm{v}$ něm sdružených a v letech 1924-1927 ve Svazu učitelek mateřských škol, jejichž byl Časopis učitelek škol mateřských tiskovým orgánem (Štraus, 1968, s. 41).

Během svého působení $\mathrm{v}$ mateřské škole v Josefské ulici v Praze se ale Ida Jarníková nevzdala realizace vlastních představ. Již v roce 1914 prosadila loutkové divadlo pro aktivizaci dětí pomocí dramatizace pohádek. Pro tyto pohádkové hry (jejichž autorkou byla většinou Ludmila Tesařová) začala sama vyrábět maňásky, což byla tehdy nevídaná novinka. Dramatizaci jako didaktický prostřredek učila Jarníková mladé adeptky od roku 1922 také na Státním učitelském ústavu pro vzdělávání pěstounek pro mateřské školy. Její zájem o pedagogické využití loutek ve výchovném a vzdělávacím procesu u předškolních dětí ji přivedl nejen $\mathrm{k}$ četným publikacím v odborném časopise Loutkár nebo v Časopise učitelek mateřských škol, ale také k účasti na četných mezinárodních konferencích (Los Angeles 1923, Drážd’any 1924, Mnichov 1927, Vídeň 1931, Paříz 1935 - Spěváček, 1975, s. 22-23).

Novým impulzem pro prosazování reformních představ $\mathrm{v}$ předškolní výchově bylo pro Idu Jarníkovou vyhlášení samostatné Československé republiky. Její aktivity se soustředily na prosazování demokratizace výchovy a Jarníková se snažila pozdvihnout úro- veň teorie, a hlavně praxe československé předškolní výchovy na evropskou úroveň. Svými články o potřebě změn $\mathrm{v}$ oblasti př́stupu $\mathrm{k}$ předškolním dětem a zejména tvrzením, že předškolní výchova není jen náhražkou nefungující rodinné péče $\mathrm{v}$ chudých vrstvách obyvatelstva, ale je potřebná pro všechny děti z důvodu získání morálních hodnot, sociální citlivosti a hygienických návyků, formovala Jarníková proměnu myšlení rodičů, dětí a hlavně dalších pěstounek (Jarníková, 1919, 1920).

Jednou z vrcholných př́ležitostí představit zástupcům učitelstva všech úrovní národního školství, ale i širší veřejnosti, návrhy na nutnou reformu předškolní výchovy, byl První sjezd československého učitelstva a přátel školství v osvobozené vlasti, který se konal ve dnech 1.-3. července 1920 v Praze pod záštitou prezidenta T. G. Masaryka (Kasperová, 2018). Mezi mnoha příspěvky byl dán prostor také problematice předškolní výchovy. Dva zásadní referáty přednesla Ida Jarníková, tehdy již celostátně a mezinárodně známá bojovnice za změny $v$ organizaci a obsahu předškolní výchovy. $V$ př́spěvcích se zabývala vývojem mateřských škol a opatroven $\mathrm{v}$ českých zemích a konfrontovala dosavadní vývoj legislativních podmínek s aktuálními potřebami a požadavky, které od roku 1907 prosazovaly moravské reformátorky v čele s Annou Süssovou a od roku 1908 také oficiální zástupkyně českých pěstounek a opatrovatelek ve známém šestnáctibodovém dokumentu Resoluce V. sjezdu pěstounek 
českých škol mateřských. Požadavky argumentované tehdy nejnovějšími výsledky lékařského a psychologického zkoumání se měly stát základem nového zákona o mateřských školách, protože zákon platný od roku 1872 již vůbec nevyhovoval. V závěru navrhla Ida Jarníková jménem Ústředního spolku pro zájmy škol mateřských rezoluci, která do značné míry opakovala požadavky reformátorek A. Süssové a I. Jarníkové z let před první světovou válkou. $\mathrm{Na}$ sjezdu vystoupila se svými požadavky na reformu mateřských škol vedle Idy Jarníkové i brněnská Anna Süssová, a to zcela $\mathrm{v}$ duchu orientace pedagogické činnosti na rozvoj osobnosti dítěte, což již obě znaly ze studia metody vědecké pedagogiky Marie Montessori. Podařilo se jim vtělit tyto požadavky i do závěrečné sjezdové rezoluce (Čálek \& Kádner, 1921, s. 208-212).

Problémy souvisejícís hledáním nové koncepce mateřské školy v podmínkách nové republiky lze shrnout do následujících tří okruhů, v jejichž prosazování byly v diskusích v odborných časopisech a při setkáních a sjezdech učitelek mateřských škol uplatňovány i argumenty z montessori pedagogiky, jak dále konkrétně uvedeme:

1. Nové pojetí cílů a obsahu předškolní výchovy. Diskuse o nich probíhala po celé meziválečné období a s výjimkou osnov pro pražské mateřské školy z roku 1938 se žádná změna neudála.
Ida Jarníková vydala v roce 1927 knihu s názvem Výchovný program mateřských škol, která po dalších téměr dvacet let poskytovala základní zaměření práce učitelek mateřských škol. Zde uplatnila také své pozitivně kritické názory na koncepci montessori.

2. Legislativní ukotvení mateřských škol v systému československého školství. $\mathrm{V}$ roce 1928 byl připraven ke schválení zákon o mateřských školách, ale byl politicky zamítnut již na ministerstvu. Správa a financování předškolní výchovy byly zásadně proměněny až po druhé světové válce. ${ }^{20}$

3. Vzdělávání učitelek a jejich sociální a právní zajištění. V roce 1923 došlo $\mathrm{k}$ vytvoření jednotné organizace $s$ názvem „Svaz učitelek mateřských škol“ se sídlem v Praze, v jehož tiskovém orgánu s názvem Časopis učitelek škol mateřských bylo v průběhu 20. let několik textů podporujících šírení koncepce montessori. Kromě dvou krátkodobých vysokoškolských kurzů (Velikonoce 1927) v Brně a Praze a vstupu učitelek mateřských škol do Školy vysokých studií pedagogických od roku 1932 se $\mathrm{v}$ př́ípravě učitelek nic zásadního neudálo.

Od 1. záŕí 1920 pracovala Jarníková v mateřské škole ve Školské ulici v Praze 2. Dne 18. záŕí 1922 byla po penzionování Františky Rezkové povolána jako cvičná učitelka do Státního ústavu učitelského v Praze 1, kde se soustředila

\footnotetext{
${ }^{20}$ Tesařová, L. 1930. Mateřské školy v letech 1869-1929. Časopis učitelek škol mateřských, 20(5), 78-81; 20(6), 98-101; 20(7), 119-122.
} 
na přípravu pěstounek a vychovatelek mateřských škol, a to až do 31. ledna 1939, kdy odešla do penze. ${ }^{21}$

V osobním výkazu Idy Jarníkové jsou zachovány také zajímavé údaje o ročním služném, tedy mzdě. Jako pracovnice Státního učitelského ústavu byla zpočátku zařazena do VII. třídy 1 . stupně se služným ve výši $24000 \mathrm{Kč}$ ročně. Po šesti letech (v roce 1928) byla zařazena do 10. stupně jako ostatní učitelky ručních prací s ročním služným po všech příplatcích ve výši 29040 Kč. Od roku 1933 jí byly zvýšeny př́íplatky a činovné a její celkový roční př́ijem tak až do roku 1939 činil 30900 Kč, což byla částka zajištující pro jednu osobu dobrý střední standard života $\mathrm{v}$ tehdejších podmínkách.

\section{STUdIUM ZaHRANIČNÍCH \\ PRAMENU゚ A KONCEPCÍ}

Po vzniku samostatného státu na podzim 1918 se v dalších letech naplno rozvinula velká diskuse o podobě mateřského školství a předškolní výchovy vůbec. Řada přívrženců a přívrženkyň implementace zahraničních (ale $\mathrm{z}$ nich především neněmeckých) modelů se snažila prosadit představy pedagogů většinou z románské kulturní a jazykové oblasti (např. Montessori, Claparède nebo Decroly) do koncepce národní výchovy, ve které měly zcela logicky dominovat představy a názory J. A. Komenského a částečně i J. V. Svo- body. Naděje obou „táborư byly upínány k Prvnímu sjezdu učitelstva a prátel školy v osvobozené vlasti, který se konal ve dnech 1.-3. července $1920 \mathrm{v}$ Praze pod záštitou, a první den i za osobní účasti prezidenta T. G. Masaryka, o kterém již bylo hovořeno.

Předškolní výchova se - dosud přes veškeré úsilí reformátorek nezačleněna právně do systému národního školství ocitla mimo povolené individualistické pokusy v oblasti školství 20. let, ale školství se vyvíjelo jako celek a myšlení učitelek mateřských škol bylo ovlivňováno inspirativními názory reformních pedagogů ze zahraničí. Řada drobných, ale důležitých momentů týkajících se šírení montessori pedagogiky se odehrávala v Československu prakticky každým rokem až do vypuknutí nové války v roce 1939.

Už v roce 1923 zahájil v odborném časopise Pedagogické rozhledy diskusi o pojetí a chápání pedagogiky Marie Montessori jako první z velkých osobností české pedagogiky učitel-elementarista Josef Kubálek, který upozornil na to, že „učitelky mateřských škol chtěly by asi přijmouti zásady Montessoriové, které přinášejí osvobození ne snad od Fröbela, ale od útlaku německé tradice, která spoutala je i dítě. Ale odborníkům teoretikům ukládá národní sebevědomí, aby obhájili Fröbela proti Montessoriové, kdo nakonec zvítězí, nelze říci.“22 Proto byla popularita

\footnotetext{
${ }^{21}$ Archiv NPMK, fond Ida Jarníková, krab. 1, Dekret MŠANO č. 122080/27.

${ }^{22}$ Kubálek, J. 1923. Výchova ve školách mateřských podle Marie Montessoriové. Pedagogické rozhledy, 33(1), 4-6 a 33(8), 359, kde autor poskytl také přehled o tehdejším hodnocení montessori pedagogiky v Německu. Pozůstalost Josefa Kubálka se nachází v SOkA Hradec Králové.
} 
koncepce montessori v Německu mnohem menší než v zemích anglosaských, a protože na českou pedagogickou teorii měla stále velký vliv pedagogika německá, bylo jasné, že ani v Československu nebude mít montessori pedagogika mezi teoretiky na růžích ustláno.

$\mathrm{V}$ časopisech určených zejména učitelkám mateřských škol, v nichž bylo potřebné uveřejňovat co nejvíce analytických zpráv o pedagogické koncepci montessori, aby se jimi mohly inspirovat hlavně ty učitelky, které pracovaly přímo $s$ dětmi $v$ běžné každodenní praxi, se zpráv o montessori reformě objevovalo jen velmi poskrovnu a hlubší studie ve druhé polovině 20 . let chybí zcela. V Časopisu učitelek škol mateřských probíhala $\mathrm{v}$ uvedeném období diskuse nad reformou mateřské školy jako celku a v něm hlavně nad jednotným obsahovým programem, $\mathrm{k}$ čemuž mohla montessori pedagogika se svojí individuálností přispět jen málo, nebo naopak zcela zásadně, totiž odmítnutím cílů navrhované reformy a jako východisko pro změny použít osobnost dítěte a její rozvojové možnosti. Tak daleko ale zatím nikdo v dobové diskusi nedošel.

Ve druhé polovině 20. let se i díky překladu B. Kožíškové rozběhla v československém odborném tisku diskuse nad pedagogikou montessori s větší mírou akceptace zahraničních názorů a zkušeností. Z nich převažovaly informace o praxi Domu dětství založeného v roce 1922 ve Vídni, která se ukázala být - i díky učitelce zřejmě českého původu Lili Roubiczkové - mnohem aktivnější a přístupnější ve vstřícnosti $\mathrm{k}$ montessori pedagogice než Praha. ${ }^{23}$ Koncem 20. let se v Praze konečně rozběhl první (a na dlouhou dobu 65 let i poslední) pokus s montessori pedagogikou v praxi československých podmínek, tradic a zájmů.

České učitelky mateřských škol několikrát v letech 1925-1927 neúspěšně žádaly o umožnění hospitací ve vídeňském Domě dětí, který se bránil př́livu návštěvníků kvůli klidu na práci. Vídeňský Dům dětí se nepodařilo navštívit ani českým učitelkám mateřských škol ve Vídni, což byla ale chabá náplast na nenaplněné touhy několika málo lidí silně se snažících uvést do praxe montessori školu i v Praze. Situace se příznivě vyvinula až v roce 1927 , kdy ve Vídni vznikla rakouská Společnost Marie Montessori a ta vyzvala inspektorát vídeňských mateřských škol ke spolupráci. Inspektorka R. Endersová prosadila hospitace i pro učitelky mateřských škol z Československa. V jejich zprávách z exkurzí se objevují poznatky z praxe, konkrétní postřehy a dojmy. Popisují živý ruch ve skupinách (tř́ídách) a činorodou sebekázeň dětí. Ve zprávách

\footnotetext{
${ }^{23}$ Vídeňský Dům dětí podle Montessori byl finančně podporován také rodinou L. Roubiczkové, která bydlela v Praze. Od roku 1923 udržovala přátelský osobní kontakt s Marií Montessori, která Vídeň v březnu 1923 také navštívila. Od roku 1925 získala vídeňská mateřská škola silnou podporu středních vrstev a stala se velmi populární školou. Srov. Kahn, D., \& Barnett, E. B. (2007). Austria 1922 to 1938. Haus der Kinder, Vienna. A Montessori Journey 1907-2007: The NAMTA centenary exhibit. NAMTA Journal, 32(3), 36-39.
} 
ale převažuje popis okamžitých dojmů $\mathrm{z}$ vnějších znaků a dílčích projevů zajímavých prvků montessori pedagogiky. ${ }^{24}$ Velmi podrobnou zprávu o návštěvě vídeňských mateřských škol napsala také Ida Jarníková, která v ní zmínila i první dojmy z návštěvy vídeňské Casa dei bambini. Poukázala na stejný jev, který se projevoval u nás i u rakouských učitelek, totiž nechut něco měnit na zaběhnutém systému Fröbelově, ale pochvalovala předem prripravené podmínky vnitřního vybavení vídeňské mateřské školy a také nadšení nových učitelek, čerstvých absolventek vzdělávacího kurzu v Itálii. Litovala pouze toho, že viděla práci učitelek a dětí asi týden po otevření nového zařízení, což nemohlo vytvořit přesný obraz o praktických možnostech práce $s$ metodou montessori. ${ }^{25}$

Exkurze a hospitace ve skutečné mateřské škole montessori (byt zatím jen ve Vídni) vyvolal veliký zájem o podobu didaktického materiálu a montessori pomůcek vůbec. Původní didaktický materiál nebyl v tehdejším Československu dostupný, byl znám jen z literatury nebo vyprávění, ale začaly se hledat „české“ cesty k vytváření obdobných sad pomůcek, které by plnily stejnou funkci a zároveň mohly být mnohem levnější. Jednou z autorek tzv. výchovných hraček pro výcvik smyslů byla i pražská výtvarnice Minka Podhájská. ${ }^{26}$ Její pomůcky, na kterých se pedagogicky podílela i Ida Jarníková, inspektorka Milada Kellerováa ${ }^{27}$ a další známé reformně naladěné učitelky, byly rozděleny do šesti oblastí podle funkce: pojem zrakový, pojem o rozměrech, pojem o počítání, pojem hmatu, pojem pohybu a pojem zručnosti. $\mathrm{Na}$ rozdíl od Marie Montessori se Podhájská s českými učitelkami nesnažila o zpracování celé soustavy pomůcek podle filozofické koncepce uzavřených pravd, ale šlo jim spíše o poskytnutí dostatečného množství cenově dostupných pomůcek pro činnosti dětí $\mathrm{v}$ mateřských školách, inspirovaných praktickými činnostmi všedního dne podle $\mathrm{M}$. Montessori. Ne všechny „výchovné hračky“ respektovaly pravidlo samokontroly chyb. I tak ale tyto „výchovné hračky“ odpovídaly tehdejším moderním trendům předškolní výchovy, orientované na rozvoj smyslové citlivosti a pracovní zručnosti.

\footnotetext{
${ }^{24}$ Zprávy byly zveřejňovány v Časopise učitelek škol mateřských v letech 1926-1930.

${ }_{25}$ Jarníková, I. Z mateřských škol ve Vidni. Zájezd 29. 1. až 31. 3. 1928. Rkp. Archiv NPMK Praha, fond Ida Jarníková.

26 Vilemína Podhájská (1881-1963) byla pražská grafička, výtvarnice, ilustrátorka, pedagožka a designérka německého původu. V letech 1922-1938 vyučovala tvorbu hraček na Školském ústavu pro domácí průmysl (později Školský ústav umělecké výroby). Její tvorbu (i výchovné hračky) dokumentují sbírky Uměleckého průmyslového muzea v Praze. Dřevěné hračky podle jejích návrhủ vyráběla firma František Kyncl v Krouně. Osobní fond je uložen v Archivu Národní galerie v Praze. V současné době jsou některé exponáty vystaveny v Muzeu hraček v Hlinsku.

${ }^{27}$ Milada Kellerová (1877-1946) byla dlouholetou úspěšnou a oblíbenou školní inspektorkou pro dětské útulky a mateřské školy v Praze. Podporovala nové postupy, pokud neškodily dětem, a snažila se podpořit organizačně i materiálně výzkum montessori metody v mateřské škole U Studánky.
} 
$\mathrm{V}$ průběhu následujících let firma Köhler v Dolním Jiřetíně vyráběla pomůcky, poněkud upravené, podle návrhů Podhájské, Kellerové a Jarníkové. Již koncem 20. let $\mathrm{a} \mathrm{v}$ průběhu let 30 . probíhaly $\mathrm{v}$ různých místech republiky výstavy dětských hraček a mezi nimi se občas objevil i původní didaktický materiál montessori zapůjčený většinou z holešovické školy U Studánky. Veřejnost si sice mohla materiál prohlédnout, ale sotva byla schopná si bez názorné ukázky činnosti $s$ didaktickou pomůckou udělat o práci s materiálem dostatečně konkrétní představu.

Ve stejném roce (1927) se objevily četné inspirativní myšlenky z principů pedagogiky montessori také $\mathrm{v}$ návrhu výchovného programu mateřských škol, jehož ministerstvem schválené vydání téhož roku významně iniciovala i Ida Jarníková. ${ }^{28}$ To bylo považováno také za státní uznání principů montessori pedagogiky použitelných v praxi československých mateřských škol. K experimentálnímu ověřování pak byl již jen krůček.

\section{PŮSOBENí Idy JaRníKOVÉ V EXPERIMENTÁLNÍ MATEŘSKÉ ŠKole V Praze-Holešovicích}

Kvůli personálním problémům se otevření výzkumné mateřské školy v Praze-Holešovicích U Studánky posunulo o půl roku, ale dne 1. ledna 1928 byla škola za účasti zřizovatele, tedy Magistrátu hlavního města Prahy, slavnostně otevřena.

Vědeckým poradcem se stal nám již dobře známý psycholog a antropolog František Šeracký. Magistrát vybavil místnosti výzkumné mateřské školy didaktickým materiálem Fröbelovým a Decrolyho, protože smyslem experimentální činnosti školy bylo vyzkoušení a porovnání metod uvedených pedagogů u dětí mezi 3 a 6 lety věku $s$ metodou montessori. ${ }^{29}$ Jako reakci na oživení zájmu o montessori pedagogiku v Československu zaslala v roce 1927 italská strana do Mateřské školy U Studánky sadu materiálu jako humanitární pomoc. ${ }^{30}$ Správou výzkumné školy byla pověřena L. Zápotocká, jesle vedla F. Štěpničková a praktická pozorování prováděli vedle prof. Šerackého ještě jeho asistent F. Rameš a školní inspektorka M. Kellerová. ${ }^{31}$

Celkem bylo ve výzkumné mateřské škole (včetně jeslí) zapsáno 134 dětí, které byly rozděleny do oddělení následovně: jesle s 25 dětmi ve věku od 1,5 roku do 3 let; oddělení Ib, kde pod vedením učitelky V. Zárubové pracovalo montessori metodou 32 dětí

\footnotetext{
${ }_{28}$ Výchovný program mateřských škol. Praha: MŠANO 1927, s. 66.

${ }^{29}$ Dochované části originálního didaktického materiálu montessori získaného z Itálie jsou dnes využívány cvičnou mateřskou školou montessori při Střední pedagogické škole v Praze-Dejvicích, která se specializuje na volnočasové aktivity dětí.

${ }^{30}$ Srov. Montessori: Perché no? Pedagogica di Maria Montessori in Italia e nel mondo? Milano: Franco Angeli 2000, nestr. ${ }^{31}$ Výzkumná mateřská škola U Studánky. Časopis učitelek škol mateřských, 1926, 16(8), 105; Z výzkumné školy mateřské v Praze 7 U Studánky. Časopis učitelek škol mateřských, 1929, 19(3), 26-28.
} 
ve věku od 3 do 6 let věku; a oddělení IIb, kde bylo vyučováno učitelkou B. Starovou 34 dětí ve věku 3-6 let, stejně jako v oddělení Ib. Posledním oddělením bylo IIa, které pracovalo $s$ fröbelovskými pomůckami pod vedením učitelky Müllerové. ${ }^{32}$ Jednotlivé učitelky musely ještě plnit speciální úkoly pro jednotlivá oddělení, psychologické pozorování, sledování dětské hry a slovního projevu, rytmická cvičení tělovýchovná, vzájemnou komunikaci apod. (Šeracký, 1929). V polovině ledna 1928 pak začalo pravidelné vyučování podle pevného výzkumného plánu. V montessori oddělení Ib bylo započato s činnostmi zapínání knoflíků, $s$ měřickými tvary, rozlišováním barev, cvičením sluchu a domácími pracemi. $\mathrm{V}$ oddělení IIb byla pozornost věnována výchově smyslů, na kterou navazovala cvičení $s$ měřickými tvary a počátky průpravy pro čtení a psaní. ${ }^{33}$ Zpočátku byla výzkumu věnována i mediálně veliká pozornost, školu nebylo sice možné navštívit a hospitovat $\mathrm{v}$ ní kvůli klidu na práci, ale rodiče dětí i učitelky občas nějaké informace o vlastních dojmech vynesly. Průběh výzkumu můžeme rekonstruovat jen na základě zachovaných článků v časopisech a ve školní kronice, protože veškerá dokumentace včetně Šerackého zpráv, uložená ještě počátkem
80. let minulého století v Národním pedagogickém muzeu J. A. Komenského v Praze, byla neodpovědně ztracena a pravděpodobně je zničena.

Během prvního roku výzkumu byla $\mathrm{v}$ jednotlivých odděleních provedena měření inteligence. Bylo konstatováno, že metoda montessori dětem vyhovuje, že zejména nadanější děti zaznamenaly pokrok a většina dětí skutečně zvládla očekávané dovednosti a uměla je i v praxi běžně používat: „Ukázalo se, že metoda Dr. Montessori skutečně vede k samostatnosti a soběstačnosti, a i když nebyly některé prvky úspěšné (např. hodiny ticha), celkově lze konstatovat uspokojení z prvního roku výzkumu a uzavřít tím, že metoda Dr. Montessori je pro českou školu vhodná. “34 V roce 1928 byla do Prahy pozvána také blízká spolupracovnice M. Montessori, dr. Hammerschlagová, aby přednesla několik přednášek, zúčastnila se besed na téma montessori metoda a její využití a pomohla zhodnotit pokus U Studánky. To se však neuskutečnilo. ${ }^{35} \mathrm{~V}$ následujících letech se bohužel nepodařilo výzkum udržet v rozvoji, zájem o něj logicky upadal, protože mizely průběžné informace z tisku a také účast na př́ležitostných výstavách dětských prací ze školy U Studánky, včetně ukázek didaktického materiálu, se snižovala. ${ }^{36}$ Přitom ve stejné

\footnotetext{
32 Takto si zapsala členění Ida Jarníková ve svých poznámkách z návštěvy výzkumné mateřské školy. Archiv NPMK, fond: Pozůstalost Idy Jarníkové, sign. S374/VI-13, 437/74.

33 Tamtéž.

34 Tamtéž, s. 56.

35 Srov. L'Idea Montessori (Milano), 1928, 1(10-11), 20.

${ }^{36}$ Mateřská a základní škola U Studánky Praha 7. Kronika opatrovny a mateřské školy U Studánky.
} 
době (1929) byla v Amsterodamu založena Mezinárodní montessori asociace (Association Montessori Internationale - AMI) a v dánském Helsingøru se konala první mezinárodní montessori konference. ${ }^{37}$ Obě aktivity se vyvíjely dále bez účasti československých zástupců. ${ }^{38}$

Výzkum nebyl dokončen, i když se i v dalších školách začaly uplatňovat prvky montessori pedagogiky, komplexní uvedení metody do praxe se o několik desítek let oddálilo (Šeracký, 1929, s. 50). Je dost nesnadné určit, proč tento jediný pokus o provedení vědeckého výzkumu v komplexním uplatnění v praxi československého školství ztroskotal. Můžeme se jen domnívat, že to bylo způsobeno obecně malým zájmem o poznání metody montessori (stejně jako jiných zahraničních koncepcí), což bylo dáno jistě i minimálním zájmem státních orgánů (v čele ministerstva školství byli v té době sociální demokraté - Anton Štefánek a poté Ivan Dérer), které $\mathrm{v}$ této době již podporovalo koncepci československé reformní pedagogiky jako naplňování politického programu sociální demokracie. Byl sestaven dokument Učebný plán jednotné vnitřně diferencované školy (1929) týmem lidí v čele se sociálním demokratem Václavem Př́ihodou a od stejného roku byl plán rozvíjen pokusně na obecných a měštanských školách $\mathrm{v}$ Praze-Michli a Praze-Nuslích, ve Zlíně a v Humpolci. Předškolních zařízení se ale tento reformní plán netýkal. Obecné chápání montessori systému jako inspirace pro převzetí některých prvků a jejich modifikaci pro české prostředí byla i v rozporu se snahou Františka Šerackého systematicky metodu prověřit v její původní podobě. Paradoxně, toto pojetí mnohem lépe odpovídalo dobové snaze samotné Marie Montessori, jejiž činnost byla př́ímo určena obavami z možného zneužití či nepochopení metody. A nepochopením metody pro ni byla i jakákoli neúplná či nepřesná aplikace jejích zásad v praxi, což ostatně platí dodnes.

\section{IDA JARNÍKOVÁ A PEDAGOGIKA MARIE MONTESSORI}

Pro nás jsou důležitější zachované osobní poznámky Idy Jarníkové, která je používala jako prŕípravu na vlastní přednášky o vývoji mateřských škol a předškolní pedagogiky na Škole vysokých studií pedagogických v Praze a pro přednášky koncem 20. let v Ostravě, Litoměricích, Roudnici nad Labem nebo Potštejně. V nich zanechala svědectví, co se tehdy běžně veřejnosti sdělovalo

\footnotetext{
${ }_{37}$ Do smrti Marie Montessori v roce 1952 bylo zorganizováno celkem devět mezinárodních kongresů, ovšem pravděpodobně bez československé účasti, protože se ji nepodařilo v archivních dokumentech potvrdit. Další mezinárodní kongresy AMI se konaly v Nice (1932), Amsterdamu (1933), Rímě (1934), Oxfordu (1936), Kodani (1937), Edinburghu (1938), San Remu (1949) a Londýně (1951).

${ }^{38} \mathrm{~V}$ archivu NPMK (fond Slavín S 370) se zachovala pozvánka $\mathrm{k}$ účasti na 27. mezinárodním tréninkovém kurzu v metodě montessori, který se měl konat v první polovině roku 1937 v Londýně, zřejmě jako důsledek ohlasu mezinárodního kongresu montessori, konaného o rok dříve v Oxfordu. Není doloženo, že by se někdo z Československa tohoto kurzu zúčastnil.
} 
o pedagogice „Dr. Montessori“. Na osmerkovém formátu zaznamenala Ida Jarníková na několika stránkách své osobní názory jako podklady $\mathrm{k}$ přednáškám o rozdílech mezi pedagogikou Fröbelovou, Montessoriové a Decrolyho. Velmi výstižně formulovala i nutnost reformy vzdělávání (nejen na předškolní úrovni): „V Rakousku chtěla mít vláda občany poslušné, podřizující se - svobodná republika musí usilovati o to, aby její občané si dovedli sami vládnouti, nebot vláda má býti $\mathrm{v}$ rukou lidu, který má rovné, tajné hlasovací právo, aby si zvolil své zástupce a tím působil na utváření poměrů ve státě. Je tedy třeba zdatných pracovníků samostatných, kteří dovedou mysliti. I v domácnosti, $\mathrm{v}$ dílně, $\mathrm{v}$ kanceláři - všude se uplatní víc člověk, který nepracuje jako stroj, ale přemýšlí o své práci. Tak se pozdvihuje úroveň lidské společnosti, úroveň státu. Tak se chrání národ před zánikem, nebot' ve světové soutěži se udrží národy kulturně vyspělé. Stará škola učila tedy hlavně věřit a poslouchat, nová musí naučit myslit a jednat. ${ }^{39}$ Mezi skvělé inspirace pro reformu školy počítala Jarníková i koncepci montessori: „Dr. Montessoriová stala se světoznámou svou prací pro výchovu dětí předškolního věku, později konala pokusy s vyučováním dètí do 10 let a konečně se pokouší rozluštiti speciální otázky, např. jak na dítě působí nábo- ženství. Dr. Montessori vyšla od studia dítěte abnormálního, a poněvadž tyto děti naučila číst, psát a počítat, byla požádána, aby vyzkoušela na dětech zdravých svou metodu. Do 7 let děti čtly, psaly a počítaly jako děti z 3. tříd obecných škol, psaly dokonce i děti čtyřleté. Dr. M. je k tomu přivedla výcvikem smyslů a jiným duševním tělocvikem $s$ podporou pomůcek pro samostatnou činnost. " ${ }^{\text {"40 }}$ Pomůcky vedou $\mathrm{k}$ sebekázni a tím i $\mathrm{k}$ možnosti svobodného pohybu a jednání dítěte. Jarníková uvádí řadu konkrétních př́ikladů a ukazuje, že dítě v běžné škole nemá tyto možnosti, protože je „připoutané $\mathrm{k}$ lavici a svázané spoustou zákazů a hrozeb a život motýla pozoruje jen $\mathrm{z}$ pomůcky přišpendlené na dřevěné destičce “. ${ }^{41}$ Velmi rozhodně požaduje Jarníková změnu prostředí podle návrhů Marie Montessori, včetně vhodného nábytku a pomůcek. $\mathrm{Z}$ montessori metod vyzdvihovala Jarníková zejména výchovu k sebekázni tichem a soustředěností: „Děti se učí zacházeti se vším jemně, proto mají lehký nábytek a skleněné a porculánové nádobí, proto $\mathrm{v}$ lekcích ticha hledí zadržovati dech, aby bylo ticho dokonalé. $V$ těchto lekcích vidí Dr. M. dobré cvičení zdržeti se projevů. Všechna výchova k přesnému vnímání slouží Dr. M. též k mravnímu zdokonalení - dítě se snaží, aby stále lépe pracovalo. $Z$ výsledků své práce a svého úsilí má radost - tedy i ci-

\footnotetext{
${ }^{39}$ Archiv NPMK, fond: Pozůstalost Idy Jarníkové, osobní zápisky, sign. S374/VI-13, 437/74, s. 2-4, a koncept nových informací o Dr. Montessoriové, sign. S374/VI-5b.

${ }^{40}$ Tamtéž, s. 5-6.

${ }^{41}$ Tamtéž, s. 8.
} 
tová stránka je zasažena“. ${ }^{42}$ Dále uvádí Jarníková z názorů $M$. Montessori, že „Z výtvarných projevů uznává Dr. M. jen modelování, a to výrobu a výzdobu nádob a cihel; z kreslení uznává jen kreslení podle skutečnosti, okreslování těles a vyplňování těchto kreseb barevným čárkováním. Ostře odsuzuje kresby ilustrační, jež naše děti tolik těší a z nichž můžeme odhadovat dětskou představivost. Právě tak úplně zanedbává vyprávění pohádek dětem, aby nebylo rušené logické myšlení dětské. Nač však klade Dr. M. silný důraz, to je hygienická výchova a péče o zdraví dítěte. Má pro to různá nářadí tělocvičná, jakých se $s$ prospěchem užívá při cvičení dětí abnormálních, jež potřebují nápravných cviků. Děti chodí také po ,provaze', aby získaly tělesnou rovnováhu. Dr. M. stará se také o správnou výživu a pečlivě zaznamenává tělesný vývoj dítěte, jež měří měsíčně a váží týdně. Psychologické a sociologické zápisy podávají pak přehled o rozvoji dítěte po všech jeho stránkách. “43 Své postřehy o montessori pedagogice vložila Ida Jarníková i do svých metodických spisů Détská zamèstnáni (1929) a Cvičeni smyslových schopností (1931), kde zveřejnila i tabule $s$ obrazy pomůcek pro potřeby učitelek mateřských škol. Dalším výrazným propagačním krokem pro šíření znalostí o metodě montessori bylo zřízení Sekce pro studium metody Dr. Montessoriové při Pražské jednotě Komenského, ve které velmi aktivně působily vedle Jarníkové a Kožiškové i učitelky z mateřské školy U Studánky.

$\mathrm{Na}$ jaře roku 1933 (11. února až 6. května) byl v Praze-Podolí otevřen první vzdělávací kurz montessori. Organizovala jej Zemská ústřední jednota učitelek se svolením Ministerstva školství a národní osvěty. Přihlásilo se 97 zájemkyň a zájemců z řad mateřských škol, obecných škol, ale i škol pomocných a speciálních a školních družin. Po přednáškách předních československých znalců systému (Kožíšková, Jarníková, Kellerová, Šeracký a další) byla konána praxe $\mathrm{v}$ mateřské škole U Studánky, během níž si účastníci vyzkoušeli práci $s$ dětmi a $s$ pomůckami, z nichž část obstarala pro potřeby kurzu Zemská ústřední jednota učitelek, část zapůjčila škola U Studánky a část byla účastníky samostatně vyrobena. ${ }^{44}$

\section{DALŠí AKTIVITY A PŮSOBENÍ IDY JARNÍKOVÉ}

Díky požadavku vedoucího Komise pro učitelskou práci pro expozici chystané výstavy soudobé kultury $\mathrm{v}$ Brně (léto 1928) a v Praze (podzim 1928) Josefa Korejse se nám zachoval vcelku podrobný výčet pracovních aktivit Idy Jarníkové (samozřejmě jen do jara 1928) včetně téměř všech přednášek, kurzů

\footnotetext{
42 Tamtéž, s. 10.

43 Tamtéž, s. 13-14.

${ }^{44}$ Kurs ke studiu metody dr. Montessoriové. Časopis učitelek škol mateřských, 1923, 13(1), 17-18; Zpráva o kursu pro studium metody M. Montessoriové. Časopis učitelek škol mateřských, 1933, 23(6), 104.
} 
a dalších profesních činností, které Ida Jarníková $\mathrm{v}$ průběhu 20. let vykonávala. Jde o úctyhodný seznam aktivit $\mathrm{v}$ různých částech republiky s ohledem na její každodenní pedagogickou činnost v Praze. ${ }^{45}$

V období reformního hnutí nebyl vytvořen ucelený výchovný program pro předškolní zařízení. Učitelky si svou práci rozšiřovaly překlady z ciziny (B. Ledvinková), sběrem her, písní, básniček a pohádek (B. Studničková) a loutkovým divadlem (L. Tesařová). Až Ida Jarníková zveřejnila svůj návrh na reformu mateřské školy pod názvem Index pomůcek pro školy mateřské a nejnižši trídy škol obecných (1908). Zde rozdělila vzdělávací obsah do čtyř oblastí podle zaměřením na člověka, zvírata, rostliny a různé. Další její spis Př́ručka pro školy mateřské (1911) představuje již celý program mateřské školy. Obsah je chronologicky rozpracován podle trimestrů a týdnů. Podle konkrétních podmínek školy si učitelky $s$ jeho pomocí zpracovávaly svůj vlastní vzdělávací program. Práce mateřských škol byla nahodilá, s odlišnou kvalitou, proto se zde objevuje snaha o systémovost a zkvalitnění práce, která vyústila roku 1938 k vydání Výchovných osnov pro materskou školu $v$ hl. městě Praze. Byl to osmistránkový dokument, který neměl celostátní závaznost, ale pracovaly podle něj nejen učitelky v Praze. Plnily se tř́i základní úkoly:
- chránit zdraví dětí, starat se o jejich bezpečí, podporovat jejich růst a vývoj, odstraňovat všechny škodlivé vlivy a upravovat prostředí, ve kterém by se dětem dobře dařilo;

- připravit děti pro jejich první povinnosti, tj. práci v národní škole, podporovat jejich duševní vývoj, rozmnožovat zásobu představ, naučit děti mluvit, chápat a pracovat, zvykat je kázni a soustředění;

- zaručit dětem právo na hru a radostně prožité dětství, veškerá činnost musí být založena na zájmu dětí.

Radostná, dobře organizovaná hra je jediným způsobem učení v mateřské škole. Pracovní program má čtyři hlavní obory: řeč, poučení, práce a zábava (Opravilová \& Dostál, 1988, s. 115).

Intenzivní rozvoj mateřských škol nastal v letech 1945-1948 a byl doprovázen požadavkem na vydání celostátně závazných osnov, kterými se stal Prozatímní pracovní program pro mateřskou školu, který ale vycházel z osnov z roku 1938. V roce 1948 byl vydán nový Program pro MŠ s hlavním cílem ideologické povahy, totiž formovat a vychovávat dítě $\mathrm{v}$ uvědomělého občana oddaného socialismu. Obsah byl uspořádán do jednotlivých složek. Důraz byl kladen na mravní výchovu v duchu kolektivismu, opomíjen byl individuální př́stup (Hasíková, 2007, s. 16-17).

Aktivní učitelská služba Idy Jarníkové byla sice ukončena penzijním dekretem z ledna 1939, podle které-

${ }^{45}$ Archiv NPMK, fond Ida Jarníková. Dopis Josefa Korejse z dubna 1928, sign. S374/IV-4. 
ho Ida Jarníková odešla 1. února 1939 na zasloužený odpočinek. ${ }^{46}$ Avšak ani po penzionování nepřestala - zejména po roce 1945 , kdy se pedagogické fakulty otevřely i učitelkám mateřských škol - všemožně podporovat uskutečňování změn $\mathrm{v}$ oblasti předškolní výchovy $\mathrm{v}$ duchu svých vlastních předválečných představ a snů, které se stále velmi lišily od běžné každodenní praxe $\mathrm{v}$ předškolních zařízeních.

$\mathrm{V}$ roce 1958 byla Ida Jarníková za celoživotní pedagogickou práci ministerstvem školství poctěna čestným titulem „zasloužilá učitelka“ (Štastná, 1975/1976, s. 381).

Ještě v první polovině 60 . let minulého století se Ida Jarníková aktivně podílela na zpracovávání vzpomínek a dokumentů pamětníků na vývoj školství při Odborovém svazu pracovníků školství v sekci Dějiny učitelstva. Tuto práci již ale nedokončila. Zemřela dne 5. října 1965 v Praze v důsledku tragické nehody ve věku 86 let, když při cestě za mladší kolegyní, kterou pravidelně ošetřovala, vystupovala $\mathrm{z}$ otevřené, ale ještě jedoucí tramvaje, upadla a těžkým zraněním $v$ nemocnici podlehla. ${ }^{47}$

\section{ZÁVĚR}

Ve svých historicko-pedagogických pracích nerad formuluji konečné závě- ry. Poznání se stále vyvíjí, budoucí autoři jistě dojdou $\mathrm{k}$ novým poznatkům i jejich hodnocení a nechci jim dnes komplikovat život „definitivními“ závěry vyplývajícími ze současného stavu poznání. Přesto lze již nyní formulovat možnosti dalších úhlů pohledu z hlediska širších, ale i užších souvislostí života, a především díla Idy Jarníkové. Tak bychom mohli nabídnout její životní osudy jako tehdy typicky genderově orientovanou cestu vychovatelky, učitelky a ochraňovatelky malých dětí, aby nebyly zbytečně brzy sociálně zneužívány pro cíle světa dospělých. Z toho vyplývá snaha Idy Jarníkové prosazovat vlastní názory a představy v dobových profesních hnutích, institucích a médiích, které často sama pomáhala budovat. Tuto osvětovou činnost, později i politizovanou, podpořila a významně zkvalitnila její orientace na poznání stavu mezinárodní scény v oblasti předškolní výchovy, zejména $s$ důrazem na reformně pedagogické hnutí, které výrazně pomáhala propagovat a kultivovat doma i v zahraničí, a to nejen $v$ oblasti ryze pedagogické, ale i v proměnách eubiotického životního stylu. Některé náznaky podobných úvah lze sledovat $\mathrm{v}$ novějších vědeckých analýzách širších okolností pedagogického života $\mathrm{v}$ meziválečném období.

\footnotetext{
$\overline{46}$ Archiv NPMK, fond Ida Jarníková, Osobní výkaz, sign. č. S374-IV/1. Dekret MŠANO č. 5150/39-II-3 z 18. ledna 1939.

${ }^{47}$ V publikaci s názvem „Kdy zemřeli?““ (Praha 1970) je na s. 81 jako datum úmrtí Idy Jarníkové mylně uvedeno 28. březen 1966, které použil ve své knize České ženy v práci pedagogické i V. Spěváček (1975, s. 23).
} 


\section{Prameny}

Archiv Národního pedagogického muzea J. A. Komenského (NPMK), Praha

Národní archiv, Praha

Státní okresní archiv (SOkA) Hradec Králové

\section{Literatura}

Bad’uríková, Z. (1999). Výchovný program materských škôl podla Idy Jarníkovej. In V. Michalička (Ed.), Dejiny predškolskej výchovy na Slovensku (s. 127-131). Bratislava: ÚIPŠ, Sborník Muzea školství a pedagogiky.

Čálek, F., \& Kádner, B. (Eds.). (1921). První sjezd československého učitelstva a prátel školství $v$ osvobozené vlasti (s. 208-212). Praha: Československá obec učitelská.

Dvořáková, B. (1987). Život a dílo Idy Jarníkové. Hradec Králové: SVK - Oddělení informačních a referenčních služeb. Rešerše č. 30/87 - Dv. 3 s.

Fottová, M. (1996). Ida Jarníková. Predškolská výchova, 50(8), 3-4.

Hasíková, D. (2007). Realizace rámcového programu pro predškolni vzdèláváni u dètí se sluchovým postiženim. (Bakalářská práce). Olomouc: PedF UP.

Jarošová, J. H. (2010). Prítomnost a naplňováni kompetenci Rámcového vzdělávacího programu pro predskolni vzdèláváni v programu „Aby malé bylo velké". (Diplomová práce.) Olomouc: CTF UP.

Kasper, T., \& Kasperová, D. 2020. Nová škola v meziválečném Československu ve Zlině. Praha: Academia.

Kasper, T., Kasperová, D., \& Pánková, M. 2018. „Národni“ školstvi za prvni československé republiky. Praha: Academia.

Kasper, T., Pelcová, N., \& Sztobryn, S. (2014). Úloha osobnosti a institucí v rozvoji vzdèlanosti v evropském kontextu. Praha: Karolinum.

Kasperová, D. 2018. Československá obec učitelská v kontextu reformy vzdéláváni učitelů (ŠVSP) a reformy školy. Praha: Academia.

Kořínek, V., \& Vyčichlo, F. 1958. Akademik Vojtěch Jarník šedesátníkem. Pokroky matematiky, fyziky a astronomie, 3(1), 1-8.

Kratochvíl, L. (1939). Jarníková Ida. In Pedagogická encyklopedie. Díl I. Praha: Novina.

Kunc, J. 1970. Kdy zemreli...? Praha.

Lacinová, I. 1991/92. Ida Jarníková - živá historie předškolní výchovy. Predškolská výchova, 46(9), 6-7.

Malá československá encyklopedie. Díl III. Praha: Academia, 1986.

Mišurcová, V. 1982. 150 let mateřského školstvi v českých zemích: J. V. Svoboda a jeho následovníci. Praha: Pedagogická fakulta UK.

Moravec, J. 2003. Jan Urban Jarník. Krása našeho domova, 3(5).

Opravilová, E., \& Dostál, A. M. 1988. Úvod do predškolni pedagogiky. Praha: SPN.

Ottưv Slovník naučný nové doby. Dodatky k Velikému Ottovu slovníku naučnému. Díl 3, sv. 1. Praha: J. Otto, 1934.

Pražák, F. 1927. Počátky české školy pokusné. Praha: B. Kočí. 
Rýdl, K. 1992. Tradice a současnost alternativního pedagogického hnutív ČSFR a ve svètè. Prešov: Metodické centrum.

Spěváček, V. 1975. České ženy v práci pedagogické. Praha: Pedagogický ústav hl. m. Prahy. Spěváček, V. (1970). Počátky a základy českých škol pokusných. Plzeň: Pedagogická fakulta. Šeracký, F. 1929. Z naší výzkumné školy mateřské v Praze 7 na Studánce. In O. Chlup \&

L. Ruthans (Eds.), Nová škola mateřská. Sbornik prèednásek z teorie a prakse školy mateřské (s. 36-57). Praha.

Šmelová, E., \& Rýdl, K. 2012. Vývoj institucí pro predškolní výchovu 1869-2011. Olomouc: Univerzita Palackého.

Štastná, J. 1975/1976. Ida Jarníková (1879-1965). Socialistická škola, 16(8).

Štraus, J. 1968. Bibliografie čs. pedagogických časopisư do roku 1950. Praha: Odborový svaz pracovníků školství a vědy.

Uhlî́rová, J. 2003. Hnutí nové výchovy. Informatorium 3-8, 10(6), 7.

BibliogRAFIE IDy JaRNíKOVÉ

1908. Index pomůcek proškoly mateřské a nejnižši trídy škol obecných. Praha: v. n. 77 s.

1910/1911. Reformní hnutí v Brně i jinde. Časopis učitelek škol mateřských, 1(1), 3-4; 1(3), 2-3; 1(5), 3.

1911. Príručka pro školy mateřské. Praha: Spolek pro zájmy škol mateřských. Sv. I. $194 \mathrm{~s}$.

1913. + Drobná, Z. Dětský svèt: Návod k zamèstnáni dètí. Praha, v. n.

1913. 55 lidových tanců pro školu a di̛m. Praha: Šimáček. 78 s.

1914/1915. K reformnímu hnutí. Časopis učitelek škol mateřských, 5(1), 2-5.

1918. Jak zamèstnáme a pobavime dèti? Nástin, jak lze zamèstnati školni dèti v prázdninových koloniich, školnich a jiných útulcích a sirotčincích apod. Praha: Čs. komise pro péči o mládež. $27 \mathrm{~s}$. 1918. Jak zamèstnáme a pobavime dèti? Pro dobrovolné pomocnictvo v ústavech a pro vychovatele vůbec. Praha: Česká zemská komise. $27 \mathrm{~s}$.

1919. Demokratisace výchovy. Rokycany: v. n. 12 s.

1919-1921. Pokusná škola mateřská. Časopis učitelek škol mateřských, 9(1-2), 1-3; 9(3-4), 14-15; 9(7-8), 54-56; 9(9-10), 66-67; 10(1-2), 2-6.

1920. K reformě škol mateřských. Národní listy, 60(213), 3.

1921. Organisace mateřských škol a opatroven. První sjezd československého učitelstva a přátel školství v osvobozené vlasti (s. 43-47). Praha: ČOU.

1921. Vnitřní reorganizace mateřských škol. První sjezd československého učitelstva a přátel školství v osvobozené vlasti (s. 206-209). Praha: ČOU.

1923. Reforma školy mateřské. Časopis učitelek škol mateřských, 13(7-10), 41-47.

1925. Index pomuicek pro školy mateřské a nejnižši trídy škol obecných. 2. vyd. Praha. $77 \mathrm{s.}$

1925. K novým směrům ve výchově. Časopis učitelek škol mateřských, 15(1), 2-4.

1925. Našim dètem. Rodinná a společenská hra Pokrývanka. Praha: Dědictví Komenského. Spisy DK č. 113. 
1926 (2. vyd. 1931). Školy mateřské: jejich význam, účel a organizace, jakož i úredni predpisy.

Praha: v. n. $61 \mathrm{s.}$

1926. Návrh osnov pro mateřské školy. Časopis učitelek škol mateřských, 16(3-4), 36-39.

1927 (2. vyd. 1930). Výchovný program mateřských škol. Přehled výchovných prostředkỉ a jak jich uživati ve výchově malých dètí. Praha: v. n. $162 \mathrm{~s}$.

1929. Dětská zaměstnáni: pro úcélné zaměstnáni dètti ve školách i v rodině. Praha, v. n. $92 \mathrm{~s}$.

1930. Vývoj mateřské školy. In. V. Komárek (Ed.), Národni škola ČSR - zkušenosti a smèrnice

(s. 26-32). Brno: Společnost Pedagogického musea.

1931. Cvičeni smyslových schopnostíse zretelem k metodám racionelni výchovy. Praha: v. n. 143 s. a 20 príloh. 1933. O vodè, co v ni žije a roste. Praha: v. n. 175 s.

1934. Činná mateřská škola. Časopis učitelek škol mateřrských, 24(2), 25-26; 24(3), 35-37; 24(4), 51-52.

1934. Marie Brožová. Jubilejní článek. Časopis učitelek škol mateřských, 24(4), 59.

1935. Nástin celoroční osnovy. Časopis učitelek škol mateřských, 25(6) 110-111.

1936. Osnování na mateřské škole. Časopis učitelek škol mateřských, 26(10), 130-134.

1938. Německé mateřské školy v ČSR. Časopis učitelek škol mateřrských, 28(6), 110-113.

1938. Osnovy pro mateřské školy a rozsah hodin. Časopis učitelek škol mateřských, 28(4), 62-63. 1946/1947. První opatrovny v Praze. Předškolní výchova, 1(3-4), 26-27.

1946/1947. Svobodova „Školka“. Předškolní výchova, 1(5-6), 27-28.

prof. PhDr. Karel Rýdl, CSc.

Univerzita Pardubice, Fakulta filozofická, katedra véd o výchové;

e-mail: karel.rydl@upce.cz

RÝDL, K. Towards the Memory and Educational Heritage of Ida Jarníková: To the 100th anniversary of her principal appearance during the First Congress of Czechoslovak Teachers and Friends of School 1920

To celebrate a little-known anniversary, the study presents an analysis of the life and work of Ida Jarniková (1879-1965), a recognised pre-school educator of the 20th century. Based on research among the archival documents, the study underlines her lifelines as a complex for the first time, especially her concept of pre-school education carried out for the benefit of children and her efforts to understand the Montessori education system and lifelong education of kindergarten teachers. A selected bibliography of Ida Jarniková complements the study.

Keywords: social care, preschool education, Ida Jarniková, Maria Montessori, innovation in education 